\section{Good news, for a change}

\section{Munich}

WHEN the German science advisory council Wissenschaftsrat began last year the monumental and delicate task of evaluating all the research institutes of the former East German Academy of Sciences, researchers in both parts of Germany were fearful that German science, once unified, would emerge as less than the sum of its parts. East Germans, in particular, feared jealousy and vindictiveness from the Western evaluators, who were seen as competing for pieces of the same finite pie. "They (eastern German scientists) thought all we wanted was to turn out the lights" in their institutes, recalls Dieter Simon, chairman of Wissenschaftsrat.

But as the evaluation approached its midpoint last week, those fears have been laid to rest. A scientific infrastructure is beginning to take shape, at least on paper, in which the whole may be even more than simple addition would have indicated.

There is good news, for instance, on how many researchers from several former East Germany Academy institutes will have positions in new institutions that are now being planned. Two weeks ago, Heinz Riesenhuber, the German Research and Technology Minister, estimated that 7,000-10,000 scientific personnel could be kept on out of approximately 15,000 . The 5,000-8,000 lost positions, while unfortunate, are less than many had feared.

And in some areas, Wissenschaftsrat would like to retain an even higher percentage of researchers. In information sciences, for instance, the council recommends keeping as many as two thirds of researchers who have not already been hired by industry. In some mathematics institutes, the percentage may be even higher.

As he has done in earlier recommendations, Simon warns that the governments in Bonn and the Länder (states) must provide adequate funds to support the new institutions. Simon, who is known for not being easily ruffled, adds that the possibility that the old institutes could be shut down while their successor institutions are postponed for lack of funds, "gives me sleepless nights".

Under severe political pressure from the nearly bankrupt eastern Länder, Chancellor
Helmut Kohl agreed on 28 February that Bonn would give them an additional DM24,000 million. Alhough he sees the grant as an encouraging sign, Simon points out that the Länder have not yet promised to spend any of the new money on science. "It is still an open question whether anything filters down at all," he warns.

Perhaps the most promising sign for research in eastern Germany is the decision by Wissenschaftsrat to propose the establishment of the first Max Planck Institute in that part of the country. The proposal for a new institute in Halle dedicated to solid-state physics and electron microscopy is a recognition that the existing academy institute there is a "jewel of the former East Germany", as council spokesman Wilhelm Krull puts it.

But the recommendation is not without problems. For one, the Max Planck Gesellschaft, which would be expected to run the institute, already has highly respected institutes for solid-state physics (in Stuttgart) and electron microscopy (in Berlin). Nevertheless, Wissenschaftsrat was confident that there was little enough overlap to make a new Max Planck Institute feasible and desirable.

More challenging will be the need for

\title{
'Now it seems this whole enterprise is about to fail'
}

\section{Munich}

DIETER Simon, director of the Max Planck Institute for the History of European Law in Frankfurt, is chairman of the science council Wissenschaftsrat, which has been evaluating science in eastern Germany. Here, near the midpoint of the evaluation, he reflects on the emerging picture of how science in Germany is being unified.

"At the beginning, we all had good intentions. We saw the necessary unification of science and education as an opportunity to restructure our own obsolete system and that of East Germany and use our common resources to create a new structure. We were going to take clever advantage of a unique historical opportunity.

"Now it seems as if this enterprise is about to fail. What has happened? First, a miracle. Our much-criticized system of science and education in the West seemed to improve by the day as we learned more about the shortcomings in the system in the East.

"Sure, some of our professorships are not filled by the optimal people. But that problem pales by comparison to a system where membership in the Communist Party was a main criterion for selection.

"Sure, our universities had a poor student-faculty ratio, especially in these days of severe overcrowding. But over there, universities and institutes were not only immobile but also jam-packed full with unnecessary staff.

"Comparisons like these made it easy for us to forget our good intentions. On top of that came practical problems. The reforms had to be carried out very quickly, so that students and professors alike did not have to wait around too long, their futures hanging in the balance, before a new structure was set up.

"But our long-term goal of basic structural reform in East and West and our shortterm goal of giving concrete practical help to the East are working at cross-purposes.

"We simply do not have the time and distance to plan research centres that combine the advantages of non-university and university institutes and avoid their drawbacks. The same is true for facilities for

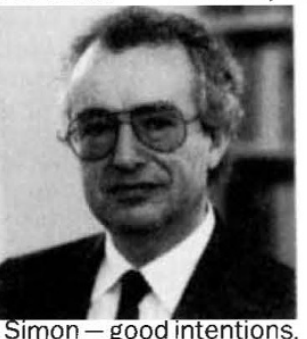

Then there is the human factor. It is easy to make recommendations. But who puts all these changes into practice? Civil servants, of course. The same inflexible petty bureaucrats who choose, with a few notable exceptions, to stay in their offices in the West instead of going east where they are needed, leaving the ministries in the East practical training, for apprenticeships and for unconventional university courses. The Western system will simply be extended eastward.

"The next problem was a conflict of goals It is not easy to bestow upon the East the the benefit of our functioning system of doing science and at the same time for both sides to move forward toward a better common future. It has to go in stages: first compatibility, then reform.

"Thus the inherent absurdity of trying to bring back research in the East from nonuniversity structures to universities, where, everyone in East and West agrees, it belongs. But in the West, just 45 per cent of federal research money goes to universities, a figure that shows no signs of changing. What kind of an example does this set? helpless to implement our recommendations.

"New ideas seem always to come up short in such a system. The tried and true 'funding instruments' we know in the West are not applied because the current conditions do not fit rules that have been invented for other situations. Instead, research groups are shoved out the door and pointed toward a 'market' that does not exist. If we are not careful projects, and entire institutions will fall through the cracks because they do not fit the dimensions of a civil servant's desk.

"We still have good intentions. But that will not be enough. We need to increase our tolerance for unorthodox solutions. We need to go to the limits of what the two systems will tolerate in our attempt to unify them. We may have to live with institutions that make us uncomfortable.

"But we cannot forget that our system is not perfect either. We have to force ourselves to remember our shortcomings every day.

"In a lot of ways, we do know better. But not in every way." 
speed in assuring the institute's future before the best researchers are lured away. Although the Max Planck Gesellschaft has traditionally followed every recommendation from Wissenschaftsrat to found a new institute, it has sometimes taken years to open them, and then only when another institute has been closed or the Gesellschaft has received a budget increase.

A spokesman for the Gesellschaft, Michael Globig, says that an internal committee will be formed, probably in June, to examine the question. The committee is expected to make a recommendation by March 1992, about the possibility of taking over the Halle institute. But the recommendation, if it comes, can be carried out only if Bonn and the Länder make new money available. "We don't plan to close another institute to open this one." says Globig.

In another important development, Wissenschaftsrat is for the first time asking policy-makers to reduce the scope of western institutions in a particular field so as to shift part of the focus of that research to the east. The advisory council is urging the western German Aerospace Research Centre (DLR) and the eastern Institute for Cosmos Research (IKF) to work together in order to make the most of the experience of IKF. This could be best achieved, says the council, by founding a new DLR institute at IKF in Berlin for planetary remote sensing, and setting up two affiliated groups to be supported by the Max Planck Gesellschaft.

The recommendation is partly an explicit recognition of the excellence of the East German space flight programme, which was well funded because of its publicity and diplomatic value for the state, demonstrated in several joint space missions with the Soviet Union. And Wissenschaftsrat has determined that space science in eastern Germany is also outstanding, especially in remote sensing and planetary science - areas where, it notes, there are some gaps in the western research programme.

One of the most surprising results of the latest round of evaluations is the relatively strong support received from Wissenschaftsrat by researchers at former East German Academy institutes for economics and social sciences - which are generally considered to have been tainted by East Germany's stateenforced Communist ideology. Simon, himself a historian of law, asserts that evaluators found some outstanding groups of researchers, isolated even within their own institutes, who are worth saving. These researchers, Simon says, are less burdened by their past than he had tought, in part because their institutes had very little internal coherence and were divided into clusters of 5 to 8 people cut off from other groups.

Wissenschaftsrat recommends that a new institute for empirical economic research be set up in eastern Germany as well as a "commission for investigating the social and political transformation of the new Länder".

Steven Dickman

\section{Where angels fear to tread...}

\section{Washington}

From fetal tissue to animal rights, the new 102nd Congress is proving that, like its predecessor, it has not met a research controversy it did not like.

Last week, Representative Henry Waxman (Democrat, New York) fired a warning shot across the bow of the administration by introducing a bill that would reverse the contentious existing ban on federally funded fetal-tissue research. It would also make break-ins and protests at animal facilities a federal crime, and boost participation of women and minorities in federally funded clinical trials.

The bill is essentially identical to a proposal Waxman introduced last year, too late to be considered as the 101st Congress drew to a close (see Nature 348, 101; 8 November 1990).

Although the legislation - with the full force of the powerful US anti-abortion movement against it - is unlikely to pass as it stands, Waxman intends to use it as an opportunity to hold hearings at which he can grill administration officials on their fetaltissue policy. Bernadine Healy, the new director of the National Institutes of Health, is expected to be called on 15 April to explain her defence of the ban (see Nature 350, 178; 21 March 1990).

Another provision in Waxman's bill joins other new and pending congressional legislation aimed at combating animal-rights attacks on research facilities. It would designate as federal crimes break-ins at federally funded health facilities, as well as protests that involve "obstruction through intimidation".

Federal offences carry stiffer penalties and investigations than simple state crimes, as most animal-related break-ins are now considered.

In the Senate, a similar break-in bill was reintroduced earlier this year by Howell Heflin (Democrat, Alabama). Heflin's bill passed the Senate last year, but the 101st Congress closed before a matching bill could be passed in the House of Representatives. That companion bill - by Texas Democrat Charles Stenholm - is also to be reintroduced soon.

Stenholm is informally circulating his legislation to gain support, and is said to have more than 100 representatives ready to sign on as cosponsors. Although the three bills differ in some details, research lobbyists are focusing their energies on the Heflin and Stenholm package as the most likely to pass. On the opposite side animal advocates are also mobilizing their forces for battle, and a stiff lobbying war over the bills is expected.

On the theory that support is where you find it, the animal activists have established an uneasy alliance with the anti-abortion movement in opposition to the break-in bills. Last week, the National Right to Life Committee came out in opposition to the Waxman provision, arguing that activist protests at animal facilities are legally similar to protests at abortion facilities - something they would not like to see made a federal offence.

Using a slightly different rationale, the American Civil Liberties Union also opposes the bill, on the grounds that deterring legitimate protest violates the First Amendment right to free speech.

Christopher Anderson

\section{LEGISLATION}

\section{A Bill of Rights for fruit and vegetables?}

\section{Washington}

AN unusual piece of legislation in Colorado has caught the attention of vegetable haters in that state. The Disparagement of Perishable Agricultural Food Products Act is aimed at discouraging slanderous campaigns about fruits, vegetables, meats and other produce.

The bill, which has passed both the Colorado State Senate and House of Representatives and needs only the signature of Governor Roy Romer to become law, has become the butt of many jokes in the press. Would President Bush be precluded from making his anti-broccoli sentiments public in the state of Colorado? Will the term 'meat-head' become actionable?

The bill is not as crazy as it sounds, says sponsor Steve Acquafresca, a legislator from a heavily agricultural part of the state. "There is a terrific need out there to provide victims of false food scares with the means to recover all or part of their damages," says he. Not vegetables themselves, mind you, but food producers.

Acquafrescas' bill was motivated in part by the Alar scare in the United States two years ago, when environmental groups launched a campaign to convince the public that small amounts of Alar, a preservative used on apples, would cause cancer. The resulting scare cost apple growers in Colorado and the rest of the country an estimated \$130 million. Under the new legislation, victims of food scares might be able to collect damages.

The requirements of the bill are fairly rigorous: in order to file a claim, the victim must show that whoever spread the rumour knew that the information was false, and it applies only to "malicious or negligent false food safety scares that are conveyed in a public campaign manner", says Acquafresca. Diana Steele 